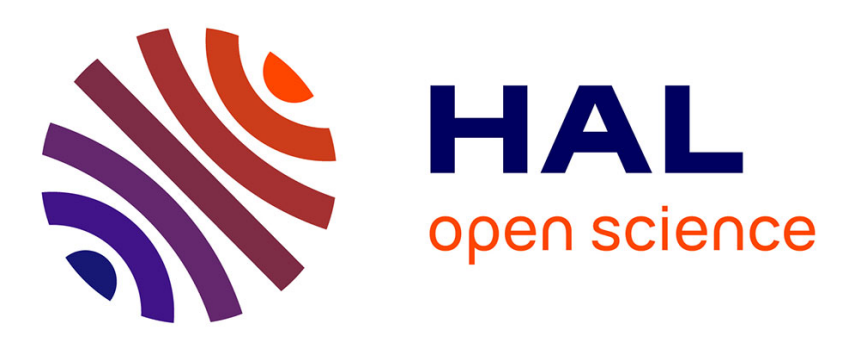

\title{
Using scenarios for forest adaptation to climate change: a foresight study of the Landes de Gascogne Forest 2050
}

Olivier Mora, Vincent Banos, Margot Regolini, Jean-Michel Carnus

\section{To cite this version:}

Olivier Mora, Vincent Banos, Margot Regolini, Jean-Michel Carnus. Using scenarios for forest adaptation to climate change: a foresight study of the Landes de Gascogne Forest 2050. Annals of Forest Science, 2014, 71 (3), pp.313-324. 10.1007/s13595-013-0336-2 . hal-01101529

\author{
HAL Id: hal-01101529 \\ https://hal.science/hal-01101529
}

Submitted on 8 Jan 2015

HAL is a multi-disciplinary open access archive for the deposit and dissemination of scientific research documents, whether they are published or not. The documents may come from teaching and research institutions in France or abroad, or from public or private research centers.
L'archive ouverte pluridisciplinaire HAL, est destinée au dépôt et à la diffusion de documents scientifiques de niveau recherche, publiés ou non, émanant des établissements d'enseignement et de recherche français ou étrangers, des laboratoires publics ou privés.

$$
\text { Copyright }
$$




\title{
Using scenarios for forest adaptation to climate change: a foresight study of the Landes de Gascogne Forest 2050
}

\author{
Olivier Mora • Vincent Banos • Margot Regolini • \\ Jean-Michel Carnus
}

Received: 12 August 2013 / Accepted: 1 October 2013 /Published online: 14 November 2013

(C) INRA and Springer-Verlag France 2013

Keywords Adaptation $\cdot$ Scenarios $\cdot$ Climate change $\cdot$ Forest planning $\cdot$ Wood sector $\cdot$ Regional scale $\cdot$ Biodiversity . Landes de Gascogne

\section{Introduction}

To ensure that forest ecosystem services will be maintained in future climate conditions, the challenge of developing and implementing forest adaptation strategies has become a priority shared across Europe (European Commission 2010)

\section{Handling Editor: Marc Hanewinkel}

Contribution of the co-authors OM, VB and MR have conducted the fieldwork, analysed the data and written the manuscript with the cooperation of JMC. OM and JMC have coordinated the "Landes de Gascogne Forest 2050" foresight study.

\section{O. Mora $(\bowtie)$}

INRA, Delegation for scientific expertise, foresight and advanced studies (DEPE), 147 rue de l'université, 75338

Paris Cedex 07, France

e-mail: olivier.mora@paris.inra.fr

\section{Banos}

National Research Institute of Science and Technology for Environment and Agriculture (IRSTEA), Amenities and Dynamics of Rural Areas research unit (UR ADBX), 50 avenue de Verdun, 33612 Cestas Cedex, France

\section{Regolini}

European Forest Institute - INRA, Joint Research Unit for Biodiversity, Genes and Communities (UMR BIOGECO), 69 Route d'Arcachon, Pierroton, 33612 Cestas Cedex, France

J.-M. Carnus

INRA, Forest, Grassland and Freshwater Ecology Department (EFPA), Bordeaux-Aquitaine Research Centre, 69 Route d'Arcachon, Pierroton, 33610 Cestas, France and around the world (FAO 2012). A critical aspect of any adaptation (and mitigation) strategy is to ensure that management choices have sufficient flexibility and are consistent with sustainable forest management (SFM) principles that balance the forest's social, ecological and economic outputs. Most current studies, however, still tend to consider forest adaptation independently of exogenous developments (Seppälä et al. 2009), or are based on forecasting and thus only extrapolate from current trends. Yet the futures of forest systems are also uncertain because change may come mainly from socio-economic, and not ecological, drivers (Schoene and Bernier 2012). Climate change will, moreover, have a highly uncertain effect on socio-ecological systems such as forests. A number of authors and international publications on the environment have posited that scenarios studies offer a framework for dealing with strong uncertainties and the complexity of socio-ecological systems: "Comparisons among a set of contrasting scenarios are used to understand the systemic interrelation and dynamics of complex socioecological systems and to define a range of possibilities and uncertainties in quantitative and qualitative terms" (Thompson et al. 2012). Likewise, SFM practices are beginning to underscore the importance of taking into account landscapelevel views of the forest, and of the many exogenous drivers of regional change, when thinking about integrated land use (Schoene and Bernier 2012). Adaptation strategies must therefore move away from single technical solutions and must not rely on one-size-fits-all mechanisms. New modes of governance that enable rapidly accelerating social, economic and institutional changes are required (Seppälä et al. 2009). Recent emphasis has also been placed on the importance of implementing regionally based forest adaptation strategies that are accepted by local stakeholders (Spathelf et al. 2013). A scenario planning approach that engages stakeholders in scenario development could be a way to overcome such 
challenges by combining anticipatory learning of climate change impacts (Tschakert and Dietrich 2010) with land use planning. Thus, forest adaptation could be seen from a perspective of forest planning rather than of forest management. It could involve a more indirect form of management that is broader in scale in terms of time, space and organisational level (Mermet and Farcy 2011).

The objective of this paper is to discuss how a foresight approach and scenario planning can offer an appropriate framework for dealing with climate change uncertainties at local level, and for elaborating a plurality of forest adaptation strategies derived from plausible sectoral, socio-ecological and regional changes. To test this assumption, the Landes de Gascogne Forest (LGF) 2050 case study (Mora et al. 2012) appears particularly interesting, due both to recent storm damage in 1999 and 2009 and because of the increasing, diverse demands in changing economic and social conditions for various forest ecosystem goods and services. The Landes region of south-western France is located at the intersection of Northern Europe and the Iberian Peninsula. It covers a surface area of about $15,000 \mathrm{~km}^{2}$. The major biophysical features of the area include temperate, oceanic climate conditions, podzolic sandy soils and shallow groundwater levels. The LGF, which was expanded in the nineteenth century to become the largest cultivated and privately owned (92\%) forest in Europe, is primarily composed of maritime pine (Pinus pinaster). The LGF covers two thirds of the Landes de Gascogne region, with agricultural and built-up land representing 18 and $7 \%$, respectively (Mora et al. 2012). The forest also has a significant economic impact through its forestry and forest-based industries. A unique aspect of the Landes forest-wood chain is the location of both timber processing stages within the region and its largely exclusive use of local maritime pine wood resources. However, the forestry and forest-based sector have faced difficulties since the Martin and Klaus storms in 1999 and 2009 that created approximately 70 million cubic metres of windthrow damage. The forestry sector is also experiencing structural challenges as synergies among industry subsectors weaken and biorefinery activities gain prominence. Bordered by the Atlantic Ocean to the west and the large urban centres of Bordeaux to the north and Bayonne to the south (Fig. 1), the Landes area has become an increasingly popular place to live and to work. Almost all of the 390 municipalities in the region are now experiencing population growth, urbanisation, the emergence of a broader base of economic activity and, more generally, a diversification of their forest-derived goods and services. The contribution of forest-related activities to the rural economy and to social well-being may change as a result of these trends (Slee et al. 2004).

This paper presents the scenario planning method as a key for investigating climate change impacts across multiple scales and domains. It then considers the driving forces underlying the current transformation of the LGF. The paper concludes by describing the different scenarios and discussing some of the results with regard to strategies of forest adaptation to climate change.

\section{Method: using scenario planning for elaborating forest adaptation strategies}

In scenario planning, a scenario is defined as a structured description of how the future may unfold, based on a coherent and internally consistent set of assumptions about key driving forces and their relationships (Henrichs et al. 2010). Scenario planning calls for the subject to be studied systemically and for forward-looking assessments to be holistic. There are generally three types of scenarios: normative, exploratory and business-as-usual (Rounsevell and Metzger 2010). Normative scenarios may be referred to as "prescriptive" or "anticipatory" scenarios. They start with a defined vision of the future and backcast to determine the conditions that will lead thereto. Business-as-usual scenarios, also called "baseline", "reference", or "predictive" scenarios, look at well-known trends to extrapolate what will happen. Exploratory scenarios, such as those used in this study, attempt to map future possibilities foreseeable in the light of currently observable trends and dynamics, taking a broad range of factors into account. By exploring "weak signals" and "early warnings" of change, exploratory scenarios are able to develop alternative visions of a situation. Their role is to stimulate discussion about possible futures.

In response to climate change, scenarios are now being used to anticipate possible futures for complex systems (Carpenter et al. 2006) that involve interactions between biotic and abiotic processes and socio-economic trends (Berkhout et al. 2002), and also to improve stakeholders and communities capacities in terms of anticipation and resilience. In highvulnerability situations (Tschakert and Dietrich 2010), scenarios thus act as learning process tools to coproduce knowledge. Shaw et al. report that "including participants from different stakeholder groups in the scenario development expanded the information that was included at the local scale (integrating local expertise) but also made the future-oriented information more relevant (futures that matter)" (2009, p 461). While there are a number of studies that rescale climate change impacts from a global level to a finer, regional or local level, few studies produce detailed local-level scenarios that integrate social, economic, or political factors (Biggs et al. 2007).

The major uncertainty taken into consideration in forestry and the forest sector is with regard to quantified projections. Hoogstra stresses that although scenario planning is not widely used, the method can be beneficial in forest management: it is "precisely the more qualitative, 'soft' 


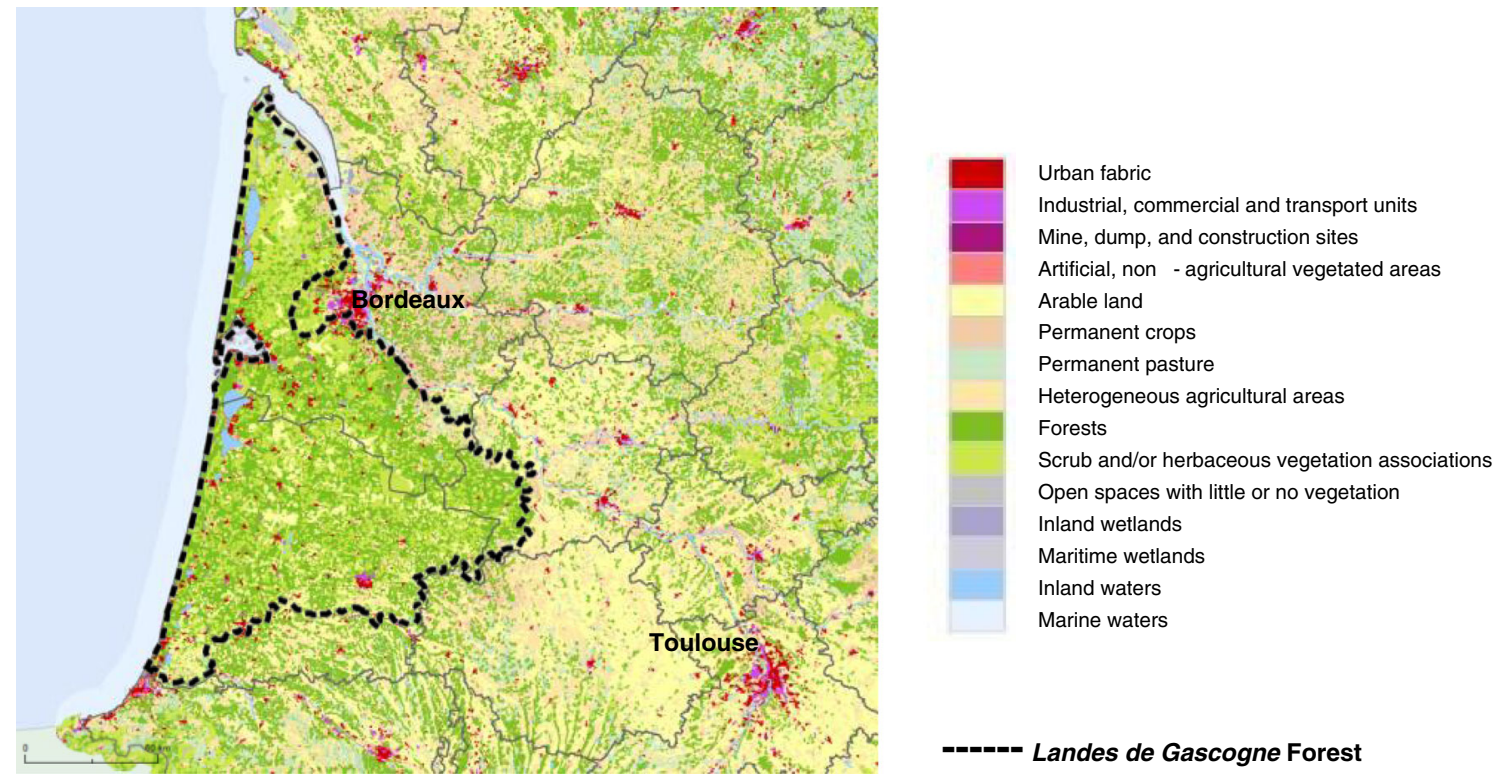

Fig. 1 Land cover in the Landes de Gascogne in 2006 (Source: UE-SOeS, CORINE Land Cover, 2006)

approach of scenario thinking, with intuition and creative thinking as central elements, which makes scenario analysis such an interesting tool for training foresters to develop future orientation, a prerequisite for effective strategic planning" (Hoogstra 2008, p 95). The use of scenario planning in forest management at national and regional levels is, however, beginning to gain ground. Notable examples of scenario planning include the "Future Forests - Sustainable Strategies under Uncertainty and Risk" project in Sweden, investigating the effects of climate change and the trade-offs between wood products and forest ecosystem services (Moen et al. 2012); the "American Forest Futures" project in the United States, which looks at socio-ecologic systems in forested regions and their response to global changes in varied long-term trends (Thompson et al. 2012); and the Canadian "Forest Futures" project, which seeks to create, with the participation of stakeholders, scenarios to sustainably manage forests and the forest-derived economy (Frittaion et al. 2011). While other foresight studies consider the futures of the forest-based sector and of wood products (COST 2011; Jonsson 2011) or use scenarios to improve the adaptiveness of community forest management (Wollenberg et al. 2000), scenario planning approach remains a relatively recent phenomenon (Hurmekoski and Hetemäki 2013).

To develop strategies of forest adaptation to climate change, the LGF study methodology involved global-tolocal downscaling, using results from biophysical modelling of climate change impacts, and addressed the future economic, social and environmental outlook for forests (Shaw et al. 2009). Faced with a complex situation where various sectors are interlinked and where structural change is likely, scenario planning in the study focused on building a number of exploratory scenarios. The study's foresight approach took into account interactions among forest, forest industry and regional drivers. To do so, it combined methods taken from territorial forward planning (Loinger 2006; Prospektiker et al. 2011) and forest-based sector foresight (Jonsson 2011), and from the study of local climate change consequences (Shaw et al. 2009).

The study was conducted between 2010 and 2012 with the following phases (adapted and modified from Godet 2002):

1. Identification of focal issue (carried out by the expert panel)

- Spatial scale: Landes de Gascogne Forest

- Time horizon: 2050

2. Assessment of the system and of its driving forces (expert panel)

- Construction of the system and identification of driving forces: demography and urbanisation; rural economy; wood chain; forest; agricultural sector; natural resources; governance

- Analysis of past trends (compilation of scientific literature, research data, interviews)

3. Scenario building

- Establishing alternative assumptions for the future of the drivers (expert panel, interviews)

- Identification of key uncertainties: link between forest and rural areas; organisation of the forest-based sector; forest adaptation to increasing risks and to climate change

- Building provisional scenarios (expert panel)

- Building final scenarios (public debates on provisional scenarios, interviews)

4. Identification of scenario outcomes for forest adaptation (expert panel, interviews, meetings)

The 2050 timeframe adopted for the LGF study was designed to align with forest management practices and with 
the current 40-year rotation cycle for maritime pine. Regional climate change projections have also been modelled to 2050; by adopting the same timeframe, the study is able to capitalise on those data.

The study used a future-oriented discussion forum to test trends and assumptions about future evolutions in the system (Mermet 2009). A project team from INRA and an expert panel participated in the forum and met ten times over a 2-year period (2010-2011). The interdisciplinary and multi-institutional group brought together researchers and stakeholders from the wood sector, local communities and environmental organizations. Interviews were also carried out with a further sixty stakeholders representing forests, industry, science research, and local authorities and municipalities. The scenarios were developed in two phases. A group of experts first prepared four provisional scenarios by combining assumptions in a coherent and internally consistent manner (Table 1); the scenarios were then discussed and finalised following public debates held in four distinctive areas of the Landes de Gascogne.

\section{Identifying three key domains for the future of the Landes de Gascogne Forest to 2050}

The expert panel first identified the driving forces of the LGF system: demographics and urbanisation; rural activities; the wood industry; the forest itself; the agricultural sector; natural resources; and governance. The panel described previous trends in these areas and identified issues regarding their possible future develop- ment. To do this, they made use of data from existing scientific studies and of stakeholder expertise while also carrying out statistical analyses in specific areas, notably with regard to demographics, employment and land use. The expert panel, as a part of the working group, then developed assumptions for each variable to 2050 by extrapolating from past and emerging trends. Some assumptions, such as those for demographics, climate trends and forest growth rates, were based on projected and quantified data while others were based on possible future discontinuities.

Table 1 Scenarios combining assumptions for each driver

\begin{tabular}{|c|c|c|c|c|}
\hline Drivers & Partial scenarios & & & \\
\hline $\begin{array}{l}\text { 1. Demography and } \\
\text { urbanisation }\end{array}$ & $\begin{array}{l}\text { Diffuse urbanisation around } \\
\text { urban centres and along } \\
\text { the coast }\end{array}$ & $\begin{array}{l}\text { Attractiveness of rural and } \\
\text { coastal areas }\end{array}$ & $\begin{array}{l}\text { Densification of urban centres, } \\
\text { and quality of urban life }\end{array}$ & $\begin{array}{l}\text { Network of cities and } \\
\text { market towns }\end{array}$ \\
\hline 2. Rural activities & $\begin{array}{l}\text { Residential economy with } \\
\text { commuting workforce }\end{array}$ & $\begin{array}{l}\text { Residential attractiveness of } \\
\text { rural-coastal areas, economic } \\
\text { engine for innovation }\end{array}$ & $\begin{array}{l}\text { Low density areas dedicated to } \\
\text { productive activities }\end{array}$ & $\begin{array}{l}\text { Territories combining } \\
\text { residential economy } \\
\text { and productive } \\
\text { activities }\end{array}$ \\
\hline 3. Wood chain & $\begin{array}{l}\text { Concentration of activities } \\
\text { focused on biomass and } \\
\text { cellulose production for } \\
\text { energy and chemistry sectors }\end{array}$ & $\begin{array}{l}\text { Creation of added value through } \\
\text { innovative SMEs and } \\
\text { reorganisation of the wood } \\
\text { sector }\end{array}$ & $\begin{array}{l}\text { Forest and wood sector serving } \\
\text { the Euroregion for energy, } \\
\text { construction, and ecosystem } \\
\text { services }\end{array}$ & $\begin{array}{l}\text { Diversification of wood } \\
\text { products for local } \\
\text { needs and exports }\end{array}$ \\
\hline 4. Forests & $\begin{array}{l}\text { Intensive forest management } \\
\text { for dendrobiomass } \\
\text { production }\end{array}$ & $\begin{array}{l}\text { Adaptation and protection of } \\
\text { maritime pine forests with } \\
\text { hedges and islands of } \\
\text { broadleaf trees }\end{array}$ & $\begin{array}{l}\text { Forest planning with segregation } \\
\text { of functions for ecosystem } \\
\text { services, wood production, } \\
\text { and recreation }\end{array}$ & $\begin{array}{l}\text { Patchwork of } \\
\text { diversified forests } \\
\text { and landscape } \\
\text { management }\end{array}$ \\
\hline $\begin{array}{l}\text { 5. Agriculture and } \\
\text { agro-industries }\end{array}$ & $\begin{array}{l}\text { Concentration of agricultural } \\
\text { firms and agro-resource } \\
\text { industries }\end{array}$ & $\begin{array}{l}\text { Interdependence between } \\
\text { agriculture and industry } \\
\text { to develop quality }\end{array}$ & $\begin{array}{l}\text { Agriculture dedicated to Euroregion } \\
\text { needs (energy, food, ecosystem } \\
\text { services) }\end{array}$ & $\begin{array}{l}\text { Territorial agricultural } \\
\text { systems and } \\
\text { diversified value } \\
\text { chains }\end{array}$ \\
\hline $\begin{array}{l}\text { 6. Natural resources } \\
\text { and land use }\end{array}$ & $\begin{array}{l}\text { Land development pressures } \\
\text { and competing uses of } \\
\text { natural resources }\end{array}$ & $\begin{array}{l}\text { Natural and cultural heritage } \\
\text { in coastal and rural areas }\end{array}$ & $\begin{array}{l}\text { Environmental zoning for resource } \\
\text { protection and land use planning }\end{array}$ & $\begin{array}{l}\text { Integrated ecosystem } \\
\text { management and } \\
\text { land use planning }\end{array}$ \\
\hline \multirow[t]{2}{*}{ 7. Governance } & $\begin{array}{l}\text { Outlying areas served by } \\
\text { metropolitan centres }\end{array}$ & $\begin{array}{l}\text { Public/private partnership and } \\
\text { contract between territories }\end{array}$ & $\begin{array}{l}\text { Euroregion planning in } \\
\text { synergy } \\
\text { with urban centres }\end{array}$ & $\begin{array}{l}\text { Local fora and } \\
\text { coordination }\end{array}$ \\
\hline & $\downarrow$ & $\downarrow$ & $\downarrow$ & $\downarrow$ \\
\hline SCENARIOS & $\begin{array}{l}\text { Urban encroachment, lack } \\
\text { of coordination }\end{array}$ & $\begin{array}{l}\text { Attractiveness of coastal-rural } \\
\text { areas, quality of products } \\
\text { and spaces }\end{array}$ & $\begin{array}{l}\text { Euroregion, food and energy } \\
\text { self-sufficiency }\end{array}$ & $\begin{array}{l}\text { Territorial patchwork, } \\
\text { diversity of forest- } \\
\text { wood chain }\end{array}$ \\
\hline
\end{tabular}


In addition to the system's endogenous drivers, five contextual exogenous driving forces influencing the future of the system were also analysed: the regional impact of climate change; future energy needs; international forest policy in regard to biodiversity, climate and carbon; international markets for wood-based products; and forest policy at other levels of governance.

Before building the scenarios, endogenous and exogenous variables were applied to the system, and uncertainties were identified, resulting in three key domains for scenario construction: the place of the forest and of the forest-based sector in the region, the organisation and driving forces of the wood-based industry, and the forest adaptation capacity to biotic and climatic hazards.

3.1 Territorial dynamics: when a predominantly forested area becomes more attractive

In past centuries, the Landes de Gascogne was viewed as a kind of "desert". Over time, the Landes became known as a rural area dedicated to forests and to agricultural activities. A growing number of people today now consider the Landes de Gascogne landscape and living conditions to be attractive. In 2006 , the area's estimated population was 839,200 ; this represents a $60 \%$ increase over the past 40 years. This population growth is not only well above national (24\%) and regional $(27 \%)$ averages, but is also constantly rising: + $8.2 \%$ from 1990 to 1999 , and $+10.5 \%$ from 1999 to 2006 (Bergouignan et al. 2011). These demographic trends contribute to urban encroachment from the cities of Bordeaux and Bayonne, to the increased appeal of coastal areas and, now, to rural resettlement as well. Under this demographic pressure, $43 \%$ of Landes de Gascogne municipalities are now located in primarily urbanised areas (Fig. 2). The forest core, once at the rural heart of Aquitaine, now runs the risk of becoming marginal periphery to urban centres (Mora et al. 2012).

As part of the demographic forecasting to 2035 carried out by Bergouignan et al. (2011) for the foresight study of the Landes de Gascogne Forest 2050, most areas of the LGF are expected to experience significant population density increases, with coastal areas most strongly affected. Population densities in the Arcachon Bay area could increase from 73 people per $\mathrm{km}^{2}$ in 2006 to 111 people per $\mathrm{km}^{2}$ by 2035. Urban encroachment from the city of Bayonne could also see densities rise from 83 to 121 people per $\mathrm{km}^{2}$ in the region's south-west. By 2035, only the central forest belt is likely to maintain low population densities under 30 people per $\mathrm{km}^{2}$.

3.2 Industrial strategies: concentration, imbalanced resource sharing, development of bioenergy

The LGF sector depends on local maritime pine wood resources, which are used across all local industries and shared among them. A large number of SMEs covering the first and the second stages of wood processing, including logging, sawing, planing, furnishing and packaging, coexist with major international pulp and paper companies and wood-based panel industries. The sustainability and competitiveness of this industrial system depends on strong complementarities based on resource sharing of wood products through the circulation of semi-finished products

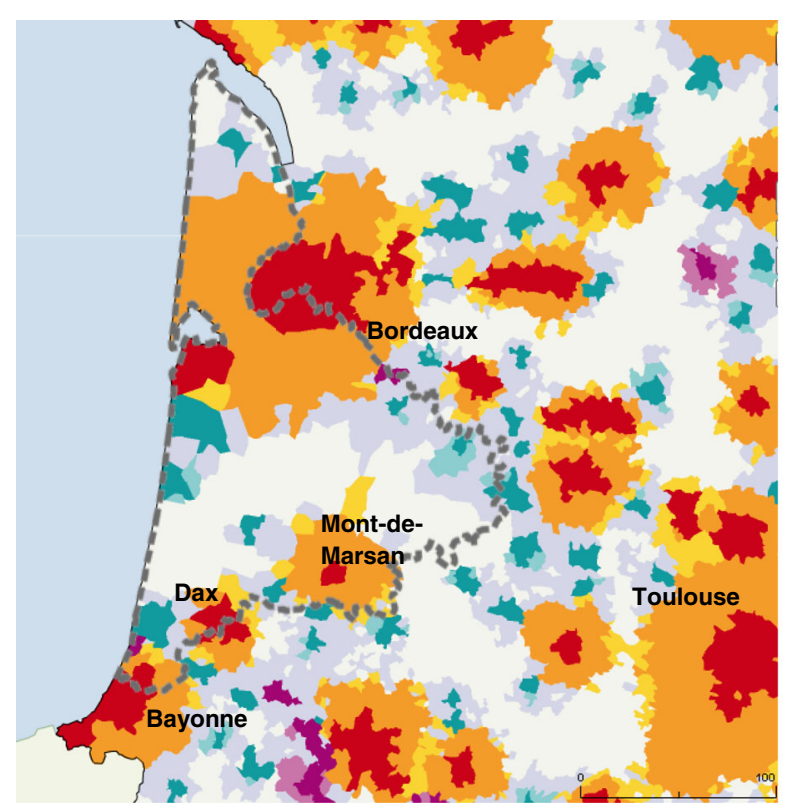

Fig. 2 Urban areas in the Landes de Gascogne (Source: DATAR-INSEE, 2010)

\section{Urban centres in 2010}

Large urban centre (more than 10,000 jobs)

Periphery of large urban centre

Area influenced by multiple large urban centres

Medium urban centre $(5,000$ to 10,000 jobs)

Periphery of medium urban centre

Small urban centre (fewer than 5,000 jobs)

Periphery of small urban centre

Other area influenced by multiple urban centres

Other municipalities (no urban centre influence) 
and residuals between timber construction and fibre industries (Bélis-Bergouignan and Levy 2010). Between 1999 and 2009, the wood used for pulp and panels manufacture increased by $22 \%$ while at the same time, wood for timber industries decreased by $20 \%$ due to the decline of some subsectors such as furniture or flooring manufacture. If current bioenergy projects using woody biomass, associated with pulp and paper industries, are taken into account, up to $25 \%$ of the annual LGF production could be used for bioenergy in 2015 (Mora et al. 2012). The future of the industrial system is therefore uncertain and existent synergies between subsectors could progressively disappear with the emergence and potential predominance of biorefinery activities producing energy, materials and bioproducts. Whatever choice is made by industry stakeholders and forest landowners, the development of different industrial products and forest services will have, in the short and long terms, a strong impact on forest management and silviculture.

\subsection{Expected impacts of climate changes on forests,} and increasing biotic and abiotic risk issues

Results of the CLIMATOR research project (Brisson and Levrault 2010) forecast climate change consequences on forest production, based on the Intergovernmental Panel on Climate Change (IPCC) median scenario (A1B) in the Aquitaine region. This scenario foresees an average $1.5{ }^{\circ} \mathrm{C}$ rise in temperatures and a $10 \%$ decrease in rainfall in the 40 years to 2050 . As a consequence, the water balance in the Landes de Gascogne region will decrease from $+200 \mathrm{~mm}$ currently to $0 \mathrm{~mm}$ in 2040 and $-200 \mathrm{~mm}$ in 2080 . This will result in increased summer water shortages, especially for forests, whose yields will be affected by both rising temperatures and increasing water deficits. The estimated impact of climate change to maritime pine production (currently around $2.6 \mathrm{tDM} / \mathrm{ha} /$ year) is a $10 \%$ decrease by 2050 and up to a $40 \%$ decrease beyond 2070 (Bosc 2011).

In the face of rapid climate change, shifts in the occurrence and magnitude of extreme weather events in the area are likely, with storms being of major concern. However, regional modelling studies of IPCC scenarios do not allow conclusions to be drawn on the possible increase of storm frequency in the Landes region (Peings et al. 2011). A recent study did show that, by 2040, the risk of forest fire in the LGF would be as high as current risk levels in France's south-eastern Mediterranean forests (Chatry et al. 2010). Moreover, because of temperature increases and rainfall decreases, the region will likely have to face longer periods of summer drought and winter saturation, stresses that are already of concern at present (Piou and Jactel 2010). Biotic risks to maritime pine are also liable to increase, with rising temperatures precipitating the arrival of opportunistic parasites and the increase of insect and pathogen populations such as pine nematode, which is likely to arrive in the region in the near future (Piou and Jactel 2010).

Initial analyses of changes in the LGF demonstrate that, in addition to the requisite knowledge of changing environmental conditions and of forest disturbance, it is also important to consider current geographic, economic and social trends affecting forests in order to bind biophysical events to socio-economic contexts (Schoene and Bernier 2012). Thus, to develop forest adaptation strategies, the future of forest products, and of forest uses, must be taken into consideration. Scenario planning offers a stimulating framework to explore these uncertainties through interlinked trajectories of biophysical, sectoral and spatial drivers, which are described in the second part of this paper.

\section{Four scenarios describing the Landes de Gascogne Forest in $\mathbf{2 0 5 0}$}

The four scenarios describing the forest, the forest-based sector and the rural area in 2050 show a wide range of possible futures.

Scenario 1 Urban encroachment, lack of coordination among forestry actors

In 2050, the forest-based sector produces renewable energy and bio-based chemical products, driven by international markets. A small number of multinational companies are organised through biorefineries, with a range of products depending on market opportunities, while others activities, such as timber processing, have decreased substantially (Fig. 3).

Changes in the wood chain have driven radical shifts in forestry towards intensive management practices, such as coppice systems and shortrotation forests. New species such as black locust (Robinia pseudoacacia), eucalyptus (Eucalyptus ssp.), and sequoia (Sequoia sempervirens) are planted in addition to, or replacing, maritime pine. Spaces are fragmented; short-rotation coppice stands coexist with peri-urban housing, farmland, logistics facilities, commercial areas, and transport infrastructure. The general "laissez-faire" situation leads to recurrent rural and land use conflicts for landscape preservation and for the protection of water resources.

Scenario 2 Attractiveness of coastal-rural areas, quality of products and spaces

In 2050, coastal areas and outlying rural areas are strongly attractive in terms of demographics and

\section{פ̂sriager}



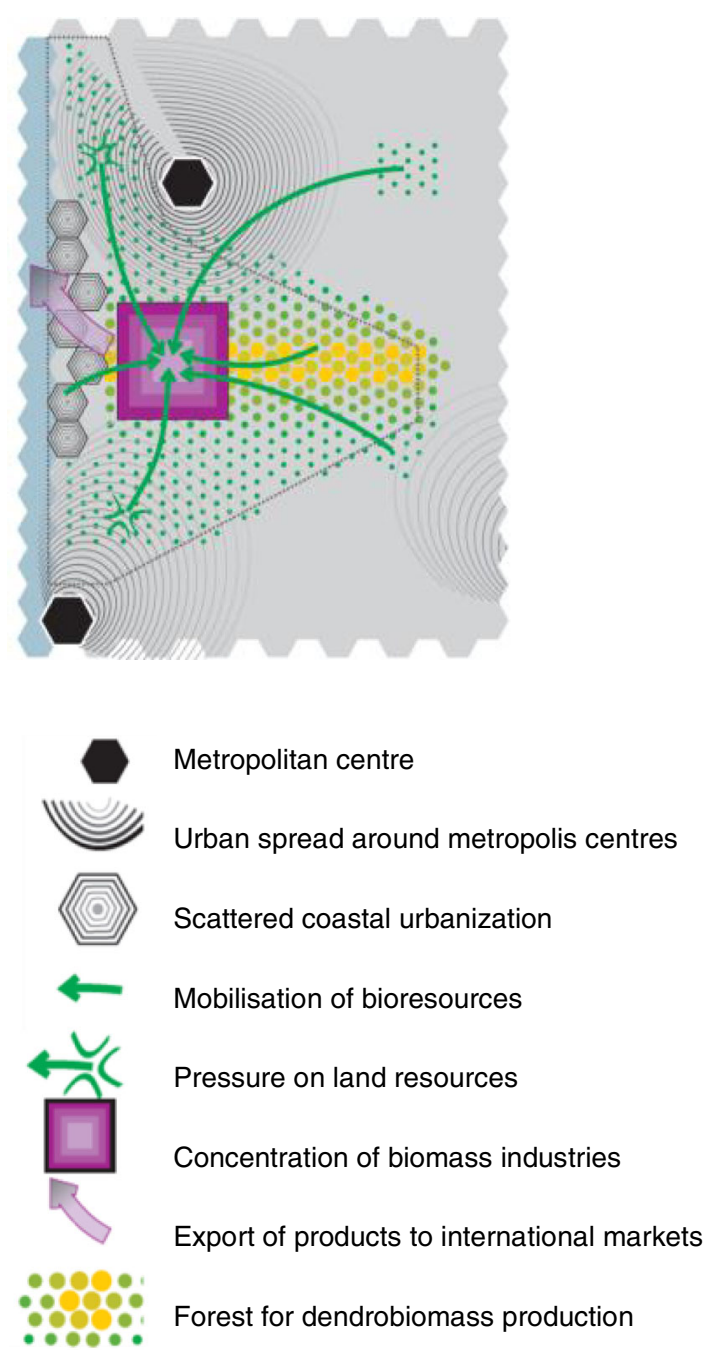

Fig. 3 Scenario 1

economics, and feature quality forest landscapes and products. This living environment where ocean, forest and nature intertwine attracts a creative class that is a driving force for the local economy and for innovation (Fig. 4).

Actors in the forest-wood chain are concerned not only with the quality of wood products, but also with the quality of landscapes and of forest ecosystems. Resilience of the maritime pine forest is reinforced through optimised forest planning and the introduction of hedges and islands of broadleaf tree species. These forest management and planning objectives produce renowned forest spaces and high-quality wood for small- and medium-sized companies that create added value. The forest-wood chain is based on a balanced organisation among actors, open to innovation, allowing the entrance of new industrial players (in the eco-construction
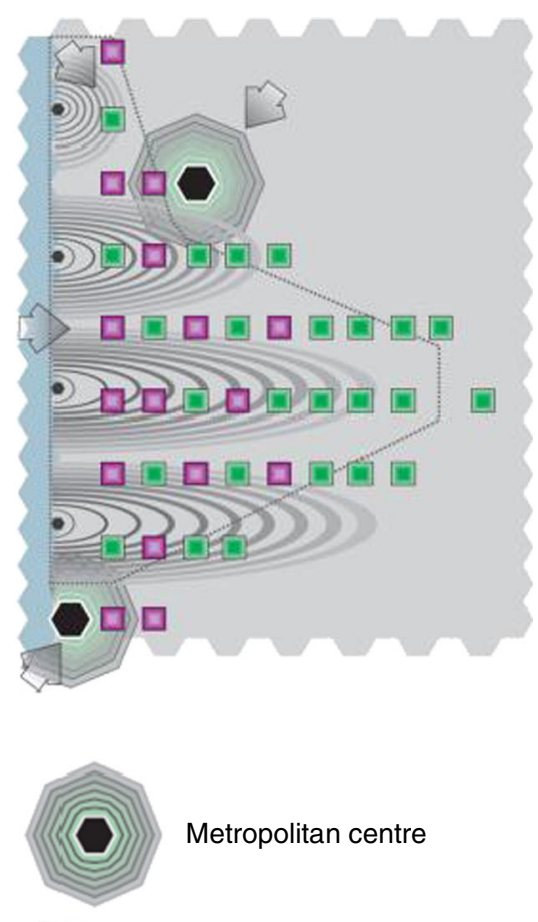

D) C) Coastal-rural system

SMEs and high added-value industries

Forests for production of high-quality wood

Demographic and economic pulls

Fig. 4 Scenario 2

sector for example), and on cross-sectoral contracting policies.

Scenario 3 Euroregion, food and energy self-sufficiency In 2050, as a part of the Aquitaine-Euskadi Euroregion, the Landes de Gascogne pursues regional, robust food and energy systems in a world driven by high energy prices. The LGF, and the region as a whole, direct their energies to improving food and energy supplies, and to providing environmental services in a general transition towards socio-ecological aims (Fig. 5).

In outlying areas, long-rotation stands of maritime pine are developed for wood production and for carbon storage. New species in coppice systems are planted and processed near logistics hubs, in order to produce biomass for energy. Those activities are performed by macro-actors such as investment funds, cooperatives, and multinational companies. Near cities, mixed forests are developed for recreation and use by 


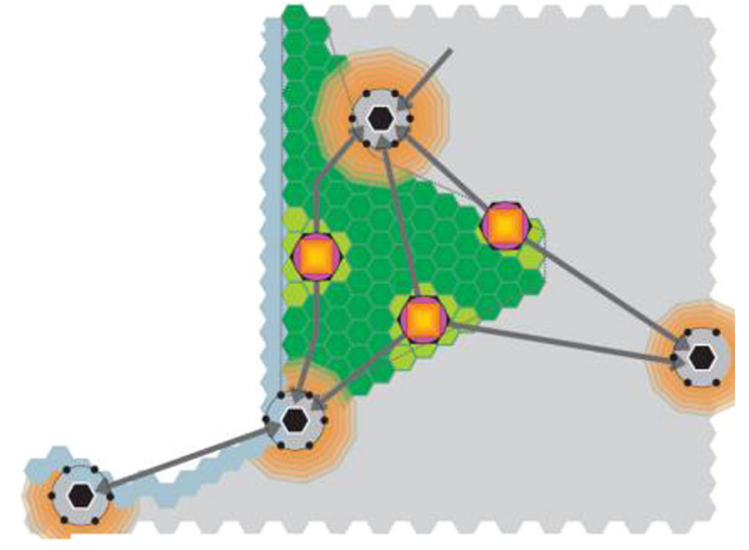

Processing centre and transport hub

Forests for wood production and ecosystem services

Biomass production areas

Metropolitan centre and densely populated periphery

Green belt for agriculture and recreation

Flows of people and goods

Fig. 5 Scenario 3

urban residents, with an agriculture green belt for food security. Spatial planning at the regional scale defines the different forest uses and characteristics.

Scenario 4 Territorial patchwork, diversity of forest-wood chains

In 2050, the Landes de Gascogne is a patchwork of territories. There are strong migration rates due to the attractiveness of rural areas organised into networks of small cities and economic activity clusters. Forest specificities have been redefined according to local and municipal goals in terms of employment, quality of life, and the local production of goods and services (Fig. 6).

Diverse tree species, including broadleaf species such as oaks and black locust, are mixed with maritime pine at landscape level. Although the forest continues to dominate land use in most areas, some areas see increased agricultural land use. Forestry actors, forestbased industries, and local residents work collectively in local fora to define land use planning and to support local innovation. Diversification and innovation in wood-based products respond to diverse needs, both from local uses and from international markets.
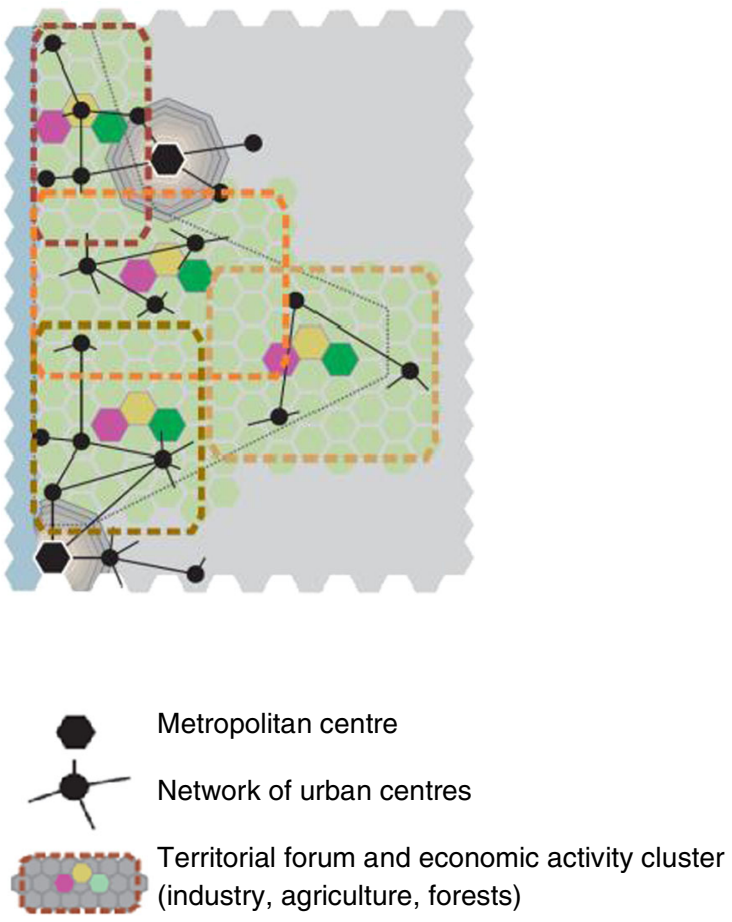
agriculture

wood sector

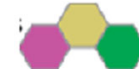

forest

Fig. 6 Scenario 4

\section{Discussions: developing diverse strategies for forest adaptation to climate change}

\subsection{Forest adaptation strategies}

Developing the four scenarios generated discussion on forest adaptation to climate change. The scenarios were characterised in particular by different forest types and by different ways to mitigate or to adapt to rising temperatures and water deficits. Four potential strategies for forest climate change adaptation were thus identified by the expert working group (Table 2).

The first strategy reflects current trends in the Landes de Gascogne, but also in various countries around the world where forest tree breeding programmes are well-established and where planted forests constitute a strategic resource for the wood-based industry, such as Brazil, Chile, Japan, New Zealand, Portugal and the UK. In Aquitaine, genetic improvement initially focused on increasing pine productivity and now also includes drought resistance in the selection criteria. In parallel, studies on other tree species and on provenance resistance to climate change are currently being carried out in this field.

The second strategy is currently being implemented as part of LGF restoration efforts following the Klaus storm. It has 
Table 2 Forest adaptation strategies

\begin{tabular}{|c|c|c|c|}
\hline Forest adaptation strategies & $\begin{array}{l}\text { Scenarios } \\
\text { concerned }\end{array}$ & Characteristics & Limits \\
\hline $\begin{array}{l}\text { 1. Selecting new tree species or provenances and } \\
\text { adapting maritime pine varieties to drought } \\
\text { tolerance }\end{array}$ & $\begin{array}{l}\text { All scenarios, } \\
\text { but } n^{\circ} 1 \text { and } \\
n^{\circ} 3 \text { in } \\
\text { particular }\end{array}$ & $\begin{array}{l}\text {-Adapt forest reproductive material through } \\
\text { genetic improvement or new provenance } \\
\text { and species introduction } \\
\text {-Introduce high productivity stands, less } \\
\text { sensitive to drought, to produce biomass }\end{array}$ & $\begin{array}{l}\text {-Decrease of biodiversity associated } \\
\text { with intensive, monospecific tree } \\
\text { plantations } \\
\text {-Increasing pressure on water } \\
\text { resources due to high yields }\end{array}$ \\
\hline $\begin{array}{l}\text { 2. Shortening production cycles to minimise } \\
\text { exposure to climatic hazards and to reduce } \\
\text { damage costs }\end{array}$ & $\begin{array}{l}\text { Scenarios } n^{\circ} 1 \\
\text { and } n^{\circ} 3\end{array}$ & $\begin{array}{l}\text {-Improve productivity and profitability } \\
\text {-Improve economic resilience by } \\
\text { decreasing risk exposure and, in } \\
\text { particular, storm damages } \\
\text {-No high-quality wood objectives }\end{array}$ & $\begin{array}{l}\text {-Possible risks of biodiversity loss } \\
\text { and pressure on water resources } \\
\text {-Possible soil carbon depletion } \\
\text { (mineralisation of organic carbon } \\
\text { due to increasing tillage) and } \\
\text { nutrient imbalance }\end{array}$ \\
\hline $\begin{array}{l}\text { 3. Associating broadleaf species with maritime } \\
\text { pine at management-unit level to increase stand } \\
\text { resistance }\end{array}$ & Scenario $\mathrm{n}^{\circ} 2$ & $\begin{array}{l}\text {-Increase ecosystem diversity and create } \\
\text { shelters for pests parasitoids and } \\
\text { predators } \\
\text {-Decrease maritime pine exposure, } \\
\text { expecting that hedgerows could be, at } \\
\text { least partially, visually and chemically } \\
\text { repulsive to insects }\end{array}$ & $\begin{array}{l}\text {-Loss of cultivated land for biomass } \\
\text { production } \\
\text { - Lack of market opportunities for } \\
\text { broadleaf tree wood }\end{array}$ \\
\hline $\begin{array}{l}\text { 4. Diversifying tree species at landscape scale and } \\
\text { managing ecotones between forests and other } \\
\text { land uses for improving habitat connectivity } \\
\text { and water regulation }\end{array}$ & Scenario $n^{\circ} 4$ & $\begin{array}{l}\text {-Landscape management of ecotones } \\
\text { between various ecosystems } \\
\text {-Forest planning at landscape level } \\
\text {-Optimise spatial organisation of various } \\
\text { land uses in order to find the best way to } \\
\text { mitigate climate change }\end{array}$ & $\begin{array}{l}\text {-Coordinating with demand from } \\
\text { biomass industry } \\
\text {-Lack of cross-sectoral coordination } \\
\text { among stakeholders } \\
\text {-Weakness of landscape management } \\
\text { tools }\end{array}$ \\
\hline
\end{tabular}

also been implemented in other European countries, for example to mitigate climate change effects on Norway spruce production by reducing the length of the rotation and by replacing Norway spruce with another spruce provenance in appropriate locations (Seppälä et al. 2009).

In the third and fourth strategies, international and regional studies have shown that diversifying tree species increases forest resilience and stand resistance to pests (Jactel and Brockerhoff 2007; GIP ECOFOR 2010) but also increases biomass production (Paquette and Messier 2011), carbon storage, and others ecosystems services (Gamfeldt et al. 2013). The third strategy is part of the recommendations for restoring the LGF following the Klaus storm, and has been implemented by a limited number of forest owners. The fourth strategy is more exploratory at present and is only in its initial stages, with new research programmes being initiated on interactions between contiguous ecosystems (forests, agrosystems, coastal ecosystems).

\subsection{Possibilities for implementing adaptation strategies,} and key issues raised

Available scientific knowledge and the local expertise of study participants informed the various adaptation strategies derived from the study scenarios. The coproduction of knowledge (Adger et al. 2007) involved and depended on a number of stakeholders whose interests are not necessarily convergent. This factor is important when implementing an adaptation strategy because such a strategy presupposes compromise and agreement-or not-among differing viewpoints regarding the conflicts that arise and on the issues at hand (Dupuis and Knoepfel 2011). To illustrate the complexity of this social process, this paper closes with an exploration of the exchanges that took place with regard to the strategies, particularly during the discussions held in the final project phase.

\subsubsection{Genetic improvement and shortened crop cycles, consensus around contentious issues}

Support by major LGF stakeholders to an adaptation strategy based on genetic improvement and shortened crop cycles rests on three key points. First is the notion that current conditions are not the only ones to which maritime pine is adapted. Second is the belief that only technical innovation will be able to deliver satisfactory adaptation solutions. Third, wood industry stakeholders seek a short-term solution to any shortage of wood resources following the storms in 1999 and 2009.

While there was stakeholder consensus on strengthening local silviculture, there were also three points of contention. First, implementing genetic improvement programmes - particularly to develop drought resistance - requires timeframes that do not align with the short-term needs of the wood industry. Scientists 
also dismissed transgenic improvement's potential usefulness. With only 2 to $3 \%$ of the target variation coming from one gene, transgenic technology is inefficient at present and poorly suited to the LGF, given the high levels of genetic variation within maritime pine. The second point of contention was raised by forest landowners. Although reducing the minimum exploitable diameter would appear logical in the light of the importance of industrial wood to the regional wood chain, some forest landowners underscore the low profitability of economic models based on biomass production. The third issue concerns the impacts of intensified silviculture on soil fertility, on carbon storage, and on biodiversity. This concern was raised both by certain forest landowners and by representatives from the scientific community. With the forest increasingly contributing to the region's attractiveness, a number of forest users and local and regional authorities also voiced their concern about the impact of intensified silviculture activity on the landscape.

\subsubsection{Species diversification management-unit level, a possible compromise?}

In the light of both economic and climatic uncertainty, forest landowners and foresters seem inclined to diversify silvicultural practices across their management units and estates, notably through the specific protection or planting of broadleaf trees species (in hedges, islands, or mixed stands). Large forestry cooperatives question this trend as it runs counter to moves for increased standardisation and would lead to higher operating costs. Current practices, however, and discussions on the issue show that a growing number of actors, including regional authorities, are already diversifying their silvicultural actions.

\subsubsection{Reconciling forest adaptation strategies and resilient socio-ecological systems}

Certain stakeholders, local authorities in particular, consider tree species diversification at management-unit level as a reductivist strategy that does not fully address existing conditions in the LGF as it becomes increasingly heterogeneous both morphologically and socio-economically. In some areas, local development now benefits less from the few gains derived from forest exploitation than from the forest's social services and contributions to the local environment and to a high quality of life, which are major draw cards for families and businesses (Slee et al. 2004). France's local forest charter programme (Chartes forestières de territoire) reflects the concern of local authorities; however the programme has otherwise struggled to free itself from industry prerogatives over forest management and to create spaces for collective decision-making (Sergent 2010) enabling multilevel industry governance. Although forest operators are now concerned that this would weaken the current-but
threatened-Landes forest model, newly emerging forms of cooperation tend to demonstrate that the issue of forest adaptation is hard to dissociate from the issue of resilience of socioecological systems where forests are located.

\section{Conclusion}

Applying a foresight approach with scenario planning tools to the study broadened the analysis of LGF adaptation to climate change in two ways. First, it encouraged socio-economic forestry stakeholders to reconcile their plans and the impact of their plans on the forest with the anticipated effects of climate change to forest and to natural environments. Second, it brought together local forest stakeholders from both the public and private sectors and it took into account the nonforestry contribution of forests to local development.

In regard to the study's objectives, this approach contributed to public debate on the adaptation issues and possibilities for the LGF. A foresight approach enabled a move away from the notion of "one best way" and allowed, by means of the scenarios, a multiplicity of forest management options to come to light. These possibilities continue to generate substantive debate and led forest stakeholders to adopt, at times, radically divergent points of view (see Section 4.2). However there are limitations for putting such research into practice. As yet, it has not been possible to devise a common forest adaptation strategy. In addition to the issue raised by disparate stakeholder viewpoints, the field of action in this area is very broad-ranging, both in a biophysical sense, from tree and stand level to ecosystem level, and in a political sense, from local municipalities to the regional government. Scenario outcomes thus call for multilevel forest governance. Yet in France, forest policy is developed at regional and national levels while land management policy rests largely in the hands of municipalities. Reconciling the two is a challenge, even within one layer of government.

Therefore, apart from improving decentralisation and coordination in multilevel and multisectoral policy-making, the main issue for forest adaptation is actually to develop an integrated land use strategy at the sub-regional level. A territorial approach seems better adapted to the ecosystem's specificities and more responsive to local, multiplestakeholder conditions. This strategy requires the development of local fora to construct local solutions that align with ecosystem specificities, territorial dynamics and sectoral relationships.

Acknowledgements The authors acknowledge the support of the Aquitaine Regional Council and the French National Institute for Agricultural Research (INRA) for steering and funding this research and wish to thank all members of the expert panel, Thomas Alban, Alain Bailly, Christophe Bergouignan, Guillaume Chantre, Agnès Charousset, Georges Cingal, Stéphane Couture, Jeoffrey Dehez, Philippe Deuffic,

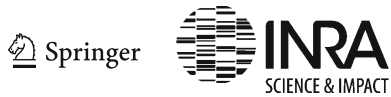


Antoine Kremer, Yves Lesgourgues, Hervé Le Treut, Bernard Itier, JeanLuc Peyron, Pierre Pouget, Olivier Roger, Henri Tardieu ${ }^{\dagger}$, Laurent Trijoulet, and its Chairman, Michel Casteigts, for their contribution to the Landes de Gascogne Forest 2050 foresight study. An initial version of this paper was presented at the "Tackling Climate Change: The Contribution of Forest Scientific Knowledge" international conference held in May 2012 in Tours, France.

\section{References}

Adger WN, Agrawala S, Mirza MMQ, Conde C, O’Brien K, Pulhin J, Pulwarty R, Smit B, Takahashi K (2007) Assessment of adaptation practices, options, constraints and capacity. In: Metz B, Davidson OR, Bosch PR, Dave R, Meyer LA (eds) Climate Change 2007: Mitigation. Contribution of Working Group III to the Fourth Assessment Report of the Intergovernmental Panel on Climate Change. Cambridge University Press, Cambridge, pp 717-744

Bélis-Bergouignan MC, Levy R (2010) Sharing a common resource in a sustainable development context: the case of a wood innovation system. Technol Forecast Soc 77:1126-1138

Bergouignan C, Inan C, LLopart M (2011) Démographie du Massif des Landes de Gascogne. Analyse rétrospective et prospective tendancielle. Rapport d'étude démographique. Institut d'Études Démographiques de l'Université Bordeaux IV, Bordeaux, $30 \mathrm{p}$

Berkhout F, Hertin J, Jordan AJ (2002) Socio-economic futures in climate change impact assessment: using scenarios as "Learning Machines". Glob Environ Chang 12:83-95

Biggs R, Raudsepp-Hearne C, Atkinson-Palombo C, Bohensky E, Boyd E, Cundill G, Fox H, Ingram S, Kok K, Spehar S, Tengö M, Timmer D, Zurek M (2007) Linking futures across scales: a dialog on multiscale scenarios. Ecol Soc 12(1): 17. http://www. ecologyandsociety.org/vol12/iss 1/art17/

Bosc A (2011) Quantification des impacts du changement climatique sur les forêts à l'échelle régionale et identification des sources d'incertitude. Presentation at the "Vulnérabilités des forêts au changement climatique" seminar, 17 November 2011, Paris

Brisson N, Levrault F (eds) (2010) Changement climatique, agriculture et forêt en France : simulations d'impacts sur les principales espèces. Le livre vert du projet Climator 2007-2010, ADEME, Paris, 336 p

Carpenter SR, Bennett EM, Peterson GD (2006) Scenarios for ecosystem services: an overview. Ecol Soc 11(1): 29. http://www. ecologyandsociety.org/vol11/iss1/art29/

Chatry C, Le Quentrec M, Laurens D, Le Gallou JY, Lafitte JJ, Creuchet B (2010) Changement climatique et extension des zones sensibles aux feux de forêts. Interministerial mission report, Paris, $90 \mathrm{p}$

COST (2011) Foresight on Future Demand for Forest-based Products and Services: Dissemination Conference. COST Strategic Workshop series, Sekocin Stary, Poland. http://www.cost.eu/events/ForestryForesight-Dissemination-Conference. Accessed 02 September 2013

Dupuis J, Knoepfel P (2011) Les barrières à la mise en œuvre des politiques d'adaptation au changement climatique: le cas de la Suisse. Swiss Polit Sci Rev 17:188-219

European Commission (2010) On Forest Protection and Information in the EU: Preparing forests for climate change, Green paper, Brussels. http://eur-lex.europa.eu/LexUriServ/LexUriServ.do?uri= COM:2010:0066:FIN:EN:PDF. Accessed 02 September 2013

FAO (2012) Forest Management and Climate Change: a literature review. Forests and Climate Change Working Paper 10. Food and Agriculture Organization of the United Nations, Rome, $55 \mathrm{p}$

Frittaion CM, Duinker PN, Grant JL (2011) Suspending disbelief: influencing engagement in scenarios of forest futures. Technol Forecast Soc 78:421-430
Gamfeldt L, Snäll T, Bagchi R, Jonsson M, Gustafsson L, Kjellander P, Ruiz-Jaen MC, Fröberg M, Stendah J, Philipson CD, Mikusinski G, Andersson E, Westerlund B, Andren H, Moberg F, Moen J, Bengtsson J (2013) Higher levels of multiple ecosystem services are found in forests with more tree species. Nat Commun 4:1340. doi: $10.1038 /$ ncomms 2328

GIP ECOFOR (2010) Expertise sur l'avenir du massif forestier de la forêt des Landes de Gascogne. Résumé pour décideurs, 14 p. http:// landes.gip-ecofor.org/data/ResumeExpertiseLandes.pdf. Accessed 02 September 2013

Godet M (2002) Foresight and territorial dynamics. Foresight 4-5:9-14

Henrichs T, Zurek M, Eickout B, Kok K, Raudsepp-Hearne C, Ribeiro T, van Vuuren D, Volkery A (2010) Scenario development and analysis for forward-looking ecosystem assessments. In: Ash $\mathrm{N}$ et al (eds) Ecosystems and Human Well-Being: A Manual for Assessment Practitioners. Island Press, pp 151-220

Hoogstra MA (2008) Coping with the long term - an empirical analysis of time perspectives, time orientations, and temporal uncertainty in forestry. $\mathrm{PhD}$ thesis. Forest and Nature Conservation Policy Group, Wageningen University, pp 91-99

Hurmekoski E, Hetemäki L (2013) Studying the future of the forest sector: review and implications for long-term outlook studies. Forest Policy Econ 34:17-29

Jactel H, Brockerhoff EG (2007) Tree diversity reduces herbivory by forest insects. Ecol Lett 10:835-848

Jonsson R (2011) Trends and possible future developments in global forest-product markets - implications for the Swedish Forest Sector. Forests 2:147-167

Loinger G (ed) (2006) Développement des territoires et prospective stratégique : enjeux, méthodes et pratiques. L'Harmattan, Paris, $225 \mathrm{p}$

Mermet L (2009) Extending the perimeter of reflexive debate on futures research: an open framework. Futures 41:105-115

Mermet L, Farcy C (2011) Contexts and concepts of forest planning in a diverse and contradictory world. Forest Policy Econ 13:361365

Moen J, Nordin A, Larsson S (2012) Future forests scenarios 2050: Possible Futures, Future Possibilities. EFP Brief (209): 4 p

Mora O, Banos V, Carnus JM, Regolini M (eds) (2012) Le massif des Landes de Gascogne à l'horizon 2050. Rapport de l'étude prospective, Aquitaine Regional Council-INRA, $290 \mathrm{p}$

Paquette A, Messier C (2011) The effect of biodiversity on tree productivity: from temperate to boreal forests. Glob Ecol Biogeogr 20:170-180

Peings H, Jamous M, Planton S, Le Treut H (2011) Scénarios climatiques: indices sur la France métropolitaine pour les modèles français ARPEGE-Climat et LMDz et quelques projections pour les DOM$C O M$. Report for the French National Plan for Adaptation, $139 \mathrm{p}$

Piou D, Jactel H (2010) L'avenir du massif forestier des Landes de Gascogne. Rapport d'expertise sur l'évaluation des risques biotiques - critère C4 risques sanitaires. GIP Ecofor, 19 p. http://landes.gipecofor.org/data/RFC40310.pdf. Accessed 02 September 2013

Prospektiker, Futuribles, Destrée Institute (Roëls CA, Destatte P, Hernaez O, Van Cutsem M, Zugasti I) (2011) An Initial Assessment of Territorial Forward Planning/Foresight Projects in the European Union. Territorial Foresight and European Multilevel Governance. Report CDR/CDP/49/2010, Committee of the Regions. $246 \mathrm{p}$

Rounsevell M, Metzger MJ (2010) Developing qualitative scenario storylines for environmental change assessment. Wiley Interdiscip Rev Clim Chang 1:606-619

Schoene DH, Bernier PY (2012) Adapting forestry and forests to climate change: a challenge to change the paradigm. Forest Policy Econ 24: $12-19$

Seppälä R, Buck A, Katila P (2009) Adaptation of forests and people to climate change: a global assessment report. Prepared by the Global Expert Panel on Adaptation of Forests to Climate Change, IUFRO World Series 22, Vienna, $51 \mathrm{p}$ 
Sergent A (2010) Régulation politique du secteur forestier en France et changement d'échelle de l'action publique. Eco rural 318-319:96110

Shaw A, Sheppard S, Burch S, Flanders D, Wiek A, Carmichael J, Robinson J, Cohen S (2009) Making local futures tangiblesynthesizing, downscaling, and visualizing climate change scenarios for participatory capacity building. Glob Environ Chang 19:447463

Slee B, Robert D, Evans R (2004) Forestry in the rural economy: a new approach to assessing the impact of forestry on rural development. Forestry $77: 441-453$

Spathelf P, van der Maaten E, van der Maaten-Theunissen M, Campioli M, Dobrowolska D (2013) Climate change impacts in European
Forests: the expert views of local observers. Ann For Sci. doi:10. 1007/s13595-013-0280-1

Thompson JR, Wiek A, Swanson FJ, Carpenter SR, Fresco N, Hollingsworth T, Spies TA, Foster DR (2012) Scenario studies as a synthetic and integrative research activity for long-term ecological research. Bioscience 62:367-376

Tschakert P, Dietrich KA (2010) Anticipatory learning for climate change adaptation and resilience. Ecol Soc 15(2): 11. http://www. ecologyandsociety.org/vol15/iss2/art11/

Wollenberg E, Edmunds D, Buck L (2000) Using scenarios to make decisions about the future: anticipatory learning for the adaptive co-management of community forests. Landsc Urban Plan 47:6577 